Joanna Król*

ORCID: 0000-0003-4500-9730

Szczecin, Poland

\title{
Loneliness in the Collective: Youth in the Socio-Educational Sphere in Poland 1948-1989
}

\section{Samotność w kolektywie: \\ młodzież w przestrzeni społeczno-edukacyjnej w Polsce w latach 1948-1989}

\begin{abstract}
Political, social and economic life in Poland in the years 1948-1989 was organised within the monocratic order. This meant the existence of one centre of power and control, as well as the subordination of all social processes to immediate political goals. Education, and especially the formation of the young generation, also found itself within the orbit of political influence. The promoted educational model was built on the ideal of the so-called socialist morality. It included, among others, idealism, the cult of work, a scientific worldview, and collectivism. Collectivism was treated as the goal, method, and the form of educational work. The compulsion to function in a group and be controlled by a group might have aroused in many members a sense of loneliness, isolation, or even rejection. The sense of rejection implied isolation. On the other hand, there was a chance to reformulate isolation into a sense of loneliness. I read loneliness as a positive value, i.e. as a journey into oneself, an opportunity for self-development and for finding an inner freedom. There-

* Dr. hab. Joanna Król, Associate Professor, Institute of Pedagogy, University of Szczecin, email: joan_krol@wp.pl.
\end{abstract}


fore, the following paradoxical questions can be posed: Was collectivism inspiring and creative, and was collectivism the source of individual emancipation? Were the youth conspiracy, youth subcultures, and all religious movements that contested the system, the proof of young people's isolation or of their creative loneliness? Answering these questions is the main goal of my paper.

Keywords: solitude; loneliness; youth; collectivism; monocentric order.

Abstrakt: Życie polityczne, społeczne i gospodarcze w Polsce w latach 1948-1989 zorganizowane było w ramach ładu monocentrycznego. Oznaczało to istnienie jednego ośrodka władzy i kontroli, a także podporządkowanie wszystkich procesów społecznych doraźnym celom politycznym. W orbicie wpływów politycznych znalazła się również edukacja, a zwłaszcza kwestia formacji młodego pokolenia. Promowany model wychowawczy zbudowany został na ideale tzw. moralności socjalistycznej. Obejmowała ona m.in. ideowość, kult pracy, światopogląd naukowy i kolektywizm. Kolektywizm potraktowano jako cel, metodę i formę pracy edukacyjnej. Przymus funkcjowania w grupie i bycie kontrolowanym przez grupę mogły u wielu budzić poczucie samotności, osamotnienia lub wręcz odrzucenia. Poczucie odrzucenia implikowało osamotnienie. $Z$ drugiej strony istniała szansa przeformułowania osamotnienia w poczucie samotności. Samotność odczytuję jako wartość pozytywną, tzn. jako drogę w głąb siebie, szansę samorozwoju i odszukania wewnętrznej wolności. Można zatem postawić następujące paradoksalne pytania: czy kolektywizm był inspirujący i twórczy, i czy kolektywizm był źródłem emancypacji jednostki? Czy konspiracja młodzieżowa, subkultury młodzieżowe oraz wszystkie ruchy religijne kontestujące system były dowodem na osamotnienie młodzieży czy też na twórczą samotność? Odpowiedź na te pytania są przewodnim celem mojego artykułu.

Slowa klucze: samotność; osamotnienie; młodzież; kolektyw; ład monocentryczny.

\section{Introduction}

Education, and the related process of acquiring knowledge, attitudes and values, always take place in a socio-political context. The particular dependence of education on political conditions can be discussed in the case of Poland in the period 1948-1989. The educational model then in force was to implement the so-called socialist morality. An important element of it was 
collectivism, which quickly became the goal, method and form of educational work with children and young people. The collective's idea was based on the unity of worldview, attitudes and actions. However, the oppressive way of implementing the collective idea made it difficult to relate this to real community. Young people who did not share the imposed judgments could feel excluded and alone. On the other hand, the inner need for freedom has made it possible to translate solitude into creative loneliness, leading to self-realization and emancipation. Opposition between on the one hand the collective understood as a community and a sense of solitude, and on the other hand the role of the collective in the birth of creative loneliness, has become the theme of the presented article. The problem is presented from the theoretical perspective, taking into account the historical and socio-educational context, which will allow the broadest possible coverage of the issue. It is also worth noting that due to the complexity of the problem, the presented article does not close the discussion, but is an invitation to further, in-depth research.

\section{Methodology of the research}

The main object of my research is loneliness in the collective. Collectivism is treated as the main goal, method, and the form of educational work in Poland in the years 1948-1989. It seems interesting to examine the connection between loneliness and the collective. Determining the nature of this interdependence is also the main purpose of the paper. I aim to provide an answer to the following paradoxical research questions: Was collectivism inspiring and creative, and was collectivism the source of individual emancipation? Were the youth conspiracy, youth subcultures, and all religious movements that contested the system, the proof of young people's isolation or of their creative loneliness?

To seek answers to the above questions, the theoretical approach has been used. The theoretical approach is typical of research in the field of the history of education, and usually involves a three-step procedure. It consists of historical reconstruction, sociological interpretation and pedagogical evaluation (Michalski, 1981, p. 16). In the case of this paper, the historical reconstruction involved recreating the historical background: namely, the main facts and events that determined the socio-political reality in Poland in years 1948-1989. Sociological interpretation and pedagogical evaluation were used to analyse the collective phenomenon, in terms of the main goal and method of working with young people; to identify the socio-educational 
effects of collectivism; and to find a connection between collectivism and creative loneliness.

\section{Collectivism and education}

Political, social and economic life in Poland in the years 1948-1989 was organised according to the monocentric order. This meant the existence of one centre of power and control, as well as the subordination of all social processes to immediate political goals (Ossowski, 1983, pp. 81-82). The process by which the communists took over and consolidated power took the form of structural and ideological Sovietization, which laid the foundations for a new social order that functioned dynamically until 1989 (Hejnicka-Bezwińska, 2015, p. 182).

The goal of both dimensions of Sovietization was to build a 'unity of representations', which was colloquially called the 'scientific world view' (Hejnicka-Bezwińska, 1996, p. 46). The implementation of such a goal was to be served by a widely understood culture, i.e. art, literature, everyday customs and education. It was extremely important to the rulers, because only through the process of internalising top-down values, knowledge and attitudes, and their reproduction, could one speak of the survival of the monocentric order. The educational activities based on a behaviourist approach (assuming the absolute educability and plasticity of human nature) were to serve this purpose (Hejnicka-Bezwińska, 2015, p. 204).

The educational model promoted at that time was built on the ideal of the so-called socialist morality. It included ideology, the work cult, a scientific worldview and collectivism (Kairow, 1950, pp. 7-45; Radziwiłł, 1981, pp. 4-9, 22-24; Mazur, 2009, pp. 325-458; Pomykało, 1977). Collectivism was treated as the goal, method and form of educational work. Anthony Makarenko, whose works formed the cornerstone of the new pedagogy, became the main theoretician, and at the same time the practitioner of the collective life (Makarenko, 1950, pp. 45-57, 75-152; Kamiński, 1948, pp. 59-69).

Collectivism primarily assumed the elimination of individual autonomy and individualism. Makarenko argued that the collective is the dialectical unity of the individual and the group (Makarenko, 1950, p. 204). Individual autonomy and individualism were considered unnecessary in a situation where the fulfilment of all human life goals was to be carried out only in the collective and by the collective. It was argued that only in a team is a man able to feel good, safe and happy. Psychological arguments were used here, claim- 
ing that the collective was supposed to satisfy the needs of affiliation, recognition and security (Kotłowski, 1968, pp. 157-180; Szczerba, 1959, pp. 437-447; Mazur, 2009, pp. 426-439). Szczerba (1959, p. 439) claimed that:

The essence of collectivism is expressed in the feeling of love and attachment to the team, for the sake of the honour of his team, and in pride in his achievements and belonging to him as a part of the team. Collectivism thus creates not only conditions for coupling the interests of the individual with the interests of the team, but also means that the interest of the individual is better and better satisfied.

It seems that the intention to organise the youth in collectives had a clear practical aspect. Young people, due to their natural qualities - i.e. energy, vitality, sacrifice, enthusiasm, openness of opinions, willingness to act - were a very desirable group for the communists (Boyd \& Bee, 2008, pp. 368-399). For the same reason, they could not be left unattended. The harnessing of the natural attributes of youth in the form of a collective was, therefore, an intentional action.

The collectivisation process was supported by formal and informal education. We can mention many actions: group pressure on the individual as one of the basic promoted educational methods, and participation of school youth in mass propaganda and political campaigns (processions, political ceremonies, drills, signing a letter of support or protest). The key political role was played by mass political youth organizations: the Polish Youth Union, the Socialist Youth Union and the Polish Socialist Youth Union. Each of these organisations, albeit with a different degree of efficiency, served short-term political interests (Król, 2015b, pp. 113-131; see: Kosiński, 2000; Kosiński, 2006; Świda-Ziemba, 2010).

The collectivisation of the life of youth, in the school and in the organisational dimension, had its distinctly dark side. The collective could give a deceptive sense of community, but the price for this was the unification of judgements, attitudes and actions. In other words, the school or organisational collective did not only control but also sanctioned the lives of its members. One can speak here about punctual behaviour (Szmatka, 2008, p. 175), where the collective oversaw members, and punished for insubordination and deviation from previously recognised rules. In the Stalinist period, such activities were carried out by, inter alia, Light Cavalry Brigades, which were to control students at school and beyond, and then administer punishments in the event of breaking any of the applicable rules (such as their poor academic perfor- 
mance, leaving the lesson, lack of social-political activity, supporting the so-called enemies of the people's state). A common sanction was enforced self-criticism carried out in the class or school forum, and in more serious situations, student suspension or expulsion from school (Świda-Ziemba, 2010, pp. 110-120).

It was mentioned that the collective was to give the individual a sense of security, belonging and unity. It also detracted from having a sense of responsibility for one's life, because it set goals and tasks for the individual to fulfil, which were then appraised. The payment for this paternalism was to be ruthless loyalty and feelings of gratitude towards the group. People seem to have been comfortable with this situation. From the point of view of developmental psychology, the collective theoretically realised one of the strongest needs of a young person, which is a strong bond with a peer group (Boyd \& Bee, 2008, pp. 368, 382-384)

However, this can only happen if the group strengthens self-esteem and self-affirmation, allows members to expand themselves and to practise new social roles, and helps them define their identity. In the case of the collective, there was no question of meeting the above conditions. The collective, as I have mentioned, was above all an oppressive and punitive group. By imposing a specific vision of the world and expecting the fulfilment of specific tasks, it acted against the young people's natural aspirations. A distinctive feature of the period of youth is the revision of one's existing opinions and the construction of a new identity. It is a period of intense development of self-awareness, of the need for self-discovery and for autonomy (Boyd \& Bee, 2008, p. 369).

Only under the aforementioned conditions can the individual's system of values and their own worldview be shaped. Not only did collectivism fail to create such conditions, but it even prevented their creation. According to Laurence Kohlberg's theory of moral development, life in the collective shaped mainly the conventional morality of the first stage, where the basis of moral judgments is the rules or norms of the group to which the individual belongs (Kielar-Turska, 2000, pp. 312-316; Boyd \& Bee, 2008, p. 390).

\section{Collectivism and loneliness}

Being compelled to operate in a group and be controlled by the group, with their private life fully transparent, may have left many people feeling lonely, isolated, or even rejected. The sense of rejection implies loneliness. 
On the other hand, it could be beneficial to reformulate isolation into a sense of loneliness. Tarnogórski (1988, p. 5) claims that: 'Higher values are often the motive for choosing loneliness'. In the case of youth in the years 1948-1989 , we can say that such values might include the need for freedom, autonomy in opinions and fidelity to principles.

I read solitude as a positive state, i.e. as a journey into oneself, an opportunity for self-development and finding one's inner freedom. In other words, it is an opportunity for personal development, based on the idea that only a lonely person can experience their individuality and uniqueness. This understanding of solitude is presented by, among others, Jan Szczepański (1980, pp. 20-28), Elżbieta Dubas (2000, pp. 129-130) and Czesław Tarnogórski (1988, pp. 4-5).

This corresponds to the developmental need for isolation and to remain in creative autonomy (its opposite is sociopoly, i.e. the tendency to be subject to social influences and to remain dependent on others) (Liberska, 2006, p. 68). The young person must thus overcome external pressures to determine his or her identity in a mature way. This is served by loneliness, or confronting oneself first with the environment, and then with oneself. 'In adolescence, loneliness is a natural time to search for values, personality transformations, and identity formation' (Wasilewska, 2010, p. 8). We can say that adolescence is a time of developmental need for isolation, because 'the state of controlled loneliness is sometimes recognized by young people as beneficial, allowing for self-analysis and reflexion upon the world' (Dołęga, 2003, p. 21).

Confronting the world and then oneself requires, however, the internal freedom mentioned above. It is the freedom that every human being needs, though it is not realised by everyone. In addition, it is the freedom that has nothing to do with the one promoted in the Polish communistic period. Freedom was then considered only in the collective category, understood as 'freedom from' (oppression in capitalist countries, moral dilemmas, fluctuations in the choice of a worldview). The sense of inner freedom is important because it is based on rebellion. From a psychological point of view, rebellion is an indispensable element of young people's development, necessary for defining their own identity. Young people creating their own system of values - and on its basis, their world view - have a natural need to rebel against limits to their freedom and independence, and against injustice and evil perceived in the social reality. Thus, the rebellion of the youth in the Polish People's Republic had a distinct socio-political aspect; that is, the state and its institutions became the object of opposition. 
Paradoxically, it was collectivism that created emancipatory attitudes and creative loneliness, which transformed into an active search for people's own and collective freedom. It can be said that oppressive actions, universal control and sanctions acted as a catalyst for personal development, which took place on the basis of loneliness. Young people, by converting the act of rejection by the collective, or noticing that its values failed to cohere with those received from the so-called Significant Others as a result of primary socialisation (Berger \& Luckmann, 2010, pp. 189-201), began the path towards creative self-development with the act of conscious loneliness.

Rebellion against the system was manifested in various forms: youth conspiracy (the youth anti-communist underground in the Stalinist years, School Social Resistance Clubs, Federation of Fighting Youth, Student Renewal Movement) (Wierzbicki, 2013; Noszczak 2016; Paleczny, 2016, pp. 39-42; Kołakowski, 2015, pp. 326-345); youth subculture/counterculture (Stalinist bikinis, skinheads, punks, hippies) (Dyoniziak, 1965; Pęczak, 1992; Filipiak, 1999); and youth movements connected with the Catholic Church (the priest Franciszek Blachnicki's overt 'Light-Life Movement', scouting chaplaincy, church groups) (Głowacka-Sobiech, 2013, pp. 120-137, 314-330; Marcinkiewicz, 2011).

These were very diverse groups in social, ideological and organisational terms. However, it can be concluded that their common features were a negative attitude to the existing socio-political reality, and the resulting need to look for their own path to self-realisation (Wierzbicki, 2013, pp. 272-273, 276-293). All of the above forms of youth activity can be considered a manifestation of counterculture understood as a contestation of applicable norms, values and patterns (Filipiak, 1999, p. 14; Paleczny, 2016, pp. 17-39). Antonina Kłoskowska wrote:

Contestation is a manifestation of the action of young people, linked in peer groups and occasionally participating in collective appearances that provide an opportunity for strong expression of attitudes ... turning against the established order to replace it with their own principles and values, which are opposed to it. (1981, p. 547)

Creative loneliness, drawing its reserves from inner freedom, caused young people to profoundly revise the vision of the world that people imposed on them; they were able to build their own value system based on the highest-order values. Often they paid the highest price for it, as exemplified by 19-year-old Grzegorz Przemyk, murdered in 1983 by Security Service 
officers. For other young people, he quickly became a symbol of the struggle for freedom and resistance to the system.

\section{Conclusions}

The analysis carried out above enables the formulation of several basic conclusions:

1. Collectivism, as one of the elements of socialist morality, was imposed as an idea that did not arise from the natural aspirations of the young people.

2. The collective assumed a unity of judgements, attitudes and actions, so it was in principle utopian.

3. Collectivism, as the basis of the educational process, was anti-developmental from its foundation. By giving an apparent sense of security and community, it at the same time denied the natural rights of youth: contestation, rebellion and the need for independence.

4. By using oppressive methods of action and emphasising the fiction of the imposed vision of the world, the process of collectivisation intensified the tendency of young people to oppose the system.

5. Youth rebellion, as a result of oppressive collectivisation, in turn led to a sense of rejection and solitude, which in many cases took the form of creative loneliness.

6. Collectivisation, therefore, paradoxically provided an opportunity for an emancipatory path to internal freedom and independence, as a factor in the self-development of the individual.

Finally, we can ask two main questions: What we should learn from this history? What is worth remembering and reflecting upon more deeply? The first answer seems to be obvious: socio-educational projects that are not consistent with human nature and do not respond to our developmental needs are utopian. In other words, their full realisation is not possible. One example of a utopian project was indeed the idea of collectivisation, which served short-term political and ideological goals. Prescribed thinking and acting was not intended to promote internal development, and the use of oppressive methods caused a feeling of solitude and isolation. On the other hand, it is a specific kind of paradox that even in such socio-educational projects that block development, there is a potential for human self-realisation. Collectivisation caused, as mentioned, solitude and isolation, but rebellion as well, which evolved into creative loneliness. This means that the internal 
human need for being free and self-realised may be so strong that even in the most oppressive conditions, people do not want to, and indeed cannot, give up these values.

\section{References}

Berger, P. \& Luckmann, T. (2010). Społeczne tworzenie rzeczywistości. Warszawa: Wydawnictwo Naukowe PWN.

Boyd, D. \& Bee, H. (2008). Psychologia rozwoju człowieka. Poznań: Zysk i S-ka Wydawnictwo.

Chłopek, M. (2005). Bikiniarze. Pierwsza polska subkultura. Warszawa: Wydawnictwo Akademickie Żak.

Dołęga, Z. (2003). Samotność młodzieży - analiza teoretyczna i studia empiryczne. Katowice: Wydawnictwo Uniwersytetu Śląskiego.

Dubas, E. (2000). Edukacja dorostych w sytuacji samotności i osamotnienia. Łódź: Wydawnictwo Uniwersytetu Łódzkiego.

Dyoniziak, R. (1965). Młodzieżowa „podkultura”. Studium socjologiczne. Warszawa: Wiedza Powszechna.

Filipiak, M. (1999). Od subkultury do kultury alternatywnej. Wprowadzenie do subkultur młodzieżowych. Lublin: Wydawnictwo UMCS.

Głowacka-Sobiech, E. (2013). Harcerstwo w Polsce w latach 1944-1990. Poznań: Wydawnictwo Naukowe im. Adama Mickiewicza.

Hejnicka-Bezwińska, T. (1996). Zarys historii wychowania (1944-1989): (oświata i pedagogika pomiędzy dwoma kryzysami). Kielce: Wydawnictwo Pedagogiczne ZNP.

Hejnicka-Bezwińska, T. (2015). Praktyka edukacyjna w warunkach zmiany kulturowej. Warszawa: Wydawnictwo Naukowe PWN SA.

Kairow, I. (ed.) (1950). Pedagogika. Vol. 2. Warszawa: Nasza Księgarnia.

Kamiński, A. (1948). Pedagogika Antoniego Makarenki. Warszawa: Robotnicze Towarztstwo Przyjaciół Dzieci.

Kielar-Turska, M. (2000). Rozwój człowieka w pełnym cyklu życia. In J. Steralau, D. Doliński (eds.), Psychologia. Vol 1: Podstawy psychologii (pp. 285-332). Gdańsk: GWP.

Kłoskowska, A. (1981). Socjologia kultury. Warszawa: Wydawnictwo Naukowe PWN.

Kołakowski, A. (2015). Opór i trwanie - ewolucja form młodzieżowego sprzeciwu wobec sowietyzacji Polski w latach 1945-1989. In A. Kołakowski (ed.), Doświadczanie dzieciństwa i młodości w Polsce (1918-1989) (pp. 326-345). Toruń: Wydawnictwo Adam Marszałek. 
Kosiński, K. (2000). O nowa mentalność: życie codzienne w szkołach 1945-1956. Warszawa. Wydawnictwo TRIO.

Kosiński, K. (2006). Oficjalne i prywatne życie młodzieży w czasach PRL. Warszawa: Rosner i Wspólnicy.

Kotłowski, K. (1968). Filozofia wartości a zadania pedagogiki. Wrocław-Warszawa-Kraków: Zakład Narodowy im. Ossolińskich.

Król, J. (2015a). Indywidualizm versus koletywizm w teorii i praktyce Związku Młodzieży Polskiej: 1948-1957. In E. Magiera (ed.), Z badań nad tradycja polskiej pedagogiki. Indywidualizm. Edukacja. Kolektywizm. Vol. 1 (pp. 139-155). Szczecin: Wydawnictwo Naukowe Wydziału Humanistycznego Uniwersytetu Szczecińskiego Minerwa.

Król, J. (2015b). Młodzież i jej zadania w dokumentach programowych ideologicznych organizacji młodzieżowych PRL. In A. Kołakowski (ed.), Doświadczanie dzieciństwa i młodości w Polsce (1918-1989) (pp. 113-131). Toruń: Wydawnictwo Adam Marszałek.

Liberska, H. (2006). Tożsamość a orientacja przyszłościowa w adolescencji. Psychologia Rozwojowa, 11(4), 65-79.

Makarenko, A. (1950). Wybrane prace pedagogiczne. Warszawa: Nasza Księgarnia.

Marcinkiewicz, M. (ed.) (2011). „Oaza wolności”. Duszpasterstwa akademickie $w$ latach siedemdziesiatych XX wieku. Szczecin: Instytut Pamięci Narodowej.

Mazur, M. (2009). O człowieku tendencyjnym... Obraz nowego człowieka $w$ propagandzie komunistycznej w Polsce i PRL 1944-1956. Lublin: Wydawnictwo UMCS.

Michalski, S. (1981). Miejsce historii wychowania w systemie nauk pedagogicznych. Bydgoskie Towarzystwo Naukowe. Prace Wydziału Nauk Humanistycznych. Seria A, 22, 1-27.

Noszczak, B. (ed.) (2016). Życie na przekór. Młodzieżowa kontestacja systemu w ostatniej dekadzie PRL (1980-1989) - nowe tropy i pytania badawcze. Warszawa: IPN.

Ossowski, S. (1983). O osobliwościach nauk społecznych. Warszawa: PWN.

Paleczny, T. (2016). Kontestacja młodzieżowa - próba zdefiniowania zjawiska. In B. Noszczak (ed.), Życie na przekór. Młodzieżowa kontestacja systemu w ostatniej dekadzie PRL (1980-1989) - nowe tropy i pytania badawcze (pp. 17-42). Warszawa: IPN.

Pęczak, M. (1992). Słownik subkultur młodzieżowych. Warszawa: Wydawnictwo Naukowe Semper.

Pomykało, W. (1977). Kształtowanie ideału wychowawczego w PRL w latach 1944-1976. Warszawa: Książka i Wiedza. 
Radziwiłł, A. (1981). Ideologia wychowawcza w Polsce w latach 1948-1956 (próba modelu). Warszawa: Niezależna Oficyna Wydawnicza „Nowa”.

Szczepański, J. (1980). Sprawy ludzkie. Warszawa: Czytelnik.

Szczerba, W. (1959). Organizacja kolektywu jako metoda wychowania moralnego. In B. Suchodolski (ed.), Zarys pedagogiki, vol. 2 (pp. 344-352). Warszawa: PWN.

Szmatka, J. (2008). Mate struktury społeczne: wstęp do mikrosocjologii strukturalnej. Warszawa: Wydawnictwo Naukowe PWN.

Świda-Ziemba, H. (2010). Młodzież PRL. Portrety pokoleń w kontekście historii. Kraków: Wydawnictwo Literackie.

Tarnogórski, Cz. (1988). Wokół samotności i osamotnienia. In M. Szyszkowska (ed.), Samotność i osamotnienie (pp. 3-18). Warszawa: Instytut Wydawniczy Związków Zawodowych.

Wasilewska, K. M. (2010). Samotność młodzieży. Bydgoszcz: Wydawnictwo Kujawsko-Pomorskiej Szkoły Wyższej w Bydgoszczy.

Wierzbicki, M. (2013). Ostatni bunt. Młodzieżowa opozycja polityczna u schytku PRL 1980-1990. Fakty, konteksty, interpretacje. Lublin-Warszawa: IPN. 